Originales

"Asociación entre el sindrome coronario agudo y el consumo de antiinflamatorios no esteroideos

Sánchez Serrano JL, Tenias Burillo JM, Chinchilla Fernández MI, Jiménez López L, Padilla Serrano A, Calleja Hernández MA.

"Departamentos de Práctica Farmacéutica en el mundo en 2006.

Castrillon Ocampo CC, Fernandez-Llimos F, Martínez-Martínez F, Gastelurrutia MA

" Establishment of criteria for the selection and adaptation of objectives and indicators in ISO9001:2008 quality system in a university pharmaceutical pilot plant.

Fàbregas-Fernández A, García-Montoya E, Pérez-Lozano P, Miñarro-Carmona M, Ticó-Grau JR, Suñé-Negre JM.

\title{
" Influence of polymethacrylates and compritol on release profile of a highly water soluble drug metformin hydrochloride.
}

Dahiya S, Onker R.

\section{Nota Clínica}

» Reacción de hipersensibilidad a carboplatino no reversible mediante protocolo de desensibilización.

Gómez de Rueda F, Gordon Santiago MM, Tena Sempere ME.

\section{Artículos Especiales}

" La Farmacia española y el comercio electrónico.

Sánchez Serrano JL, Tenias Burillo JM, Chinchilla Fernández MI, Jiménez López L, Padilla Serrano A, Calleja Hernández MA.

» Microorganismos probióticos y salud.

Sánchez MT, Ruiz MA, Morales ME. 


\title{
Influence of polymethacrylates and compritol on release profile of a highly water soluble drug metformin hydrochloride
}

\author{
Sunita Dahiya , Raginee Onker.
}

Department of Pharmaceutics, Globus College of Pharmacy, Madhya Pradesh (India).

\author{
Original Article \\ Artículo Original \\ Correspondence/Correspondencia: \\ Dr. Sunita Dahiya \\ Associate Professor \& Head of \\ the Department, Department of \\ Pharmaceutics, \\ Globus College of Pharmacy, \\ Bhojpur Road, Bhopal-462045, \\ Madhya Pradesh, India. \\ Tel.: +91-9009484272 \\ e-mail: drsunitadahiya@gmail.com
}

Competing interest / Conflicto de interes:

Undeclared

Fundings / Financiación:

Undeclared

Received: 12.07.2014

Accepted: 20.12.2014

\section{RESUMEN}

Objetivo: La presente investigación estudia EL efecto de polimetacrilato Eudragit RSPO, Y RLPO EUDRAGIT compritol 888 ATO en el perfil de liberación de un farmaco altamente soluble en agua como es el clorhidrato de metformina (MET).

Materiales y Métodos: Las dispersiones sólidas se prepararon utilizando fármaco:polímero en proporciones 1:1 y 1:5 por técnicas de coprecipitación y coevaporation. Las dispersiones sólidas se caracterizaron por espectroscopía de infrarrojo (IR), calorimetría diferencial de barrido (DSC), difracción de rayos $\mathrm{X}$ (DRX), así como uniformidad de contenido, los estudios de disolución in vitro de $0,1 \mathrm{~N} \mathrm{HCl}$ pH 1.2 , tampón fosfato $\mathrm{pH} 6.8$.

Resultados y Discusión: Los resultados de los estudios sugiere que hubo desaparición progresiva o cambios de los picos en IR, señales termotrópicos de fármaco en coevaporados y coprecipitados con aumento de la cantidad de polímeros de difracción de rayos X. Por otra parte, la liberación in vitro de MET altamente soluble en agua podría extenderse a rangos más altos de fármaco : polímero.

Conclusión: Se resume Y RLPO EUDRAGIT que había mayor capacidad de liberación de fármacos de Eudragit RSPO y Comproitol 888 y su coevaporates en 1:5:polímero relación drogas (F11)extendidos liberación de fármacos con tasas comparativamente mayor disolución $(92,15 \%$ liberación de fármacos a las 12 horas) cercano a cero orden cinética $(\mathrm{r} 2=0,9822)$.

PALABRAS CLAVE: Clorhidrato de metformina, Dispersión, Fármaco hidrosoluble, Liberación,

\section{ABSTRACT}

Aims: The present investigation studied effect of polymethacrylates Eudragit RSPO, Eudragit RLPO and compritol 888 ATO on release profile of highly water soluble drug metformin hydrochloride (MET).

Materials and Methods: The solid dispersions were prepared using drug:polymer ratios 1:1 and 1:5 by coevaporation and coprecipitation techniques. Solid dispersions were characterized by infrared Spectroscopy (IR), differential scanning calorimetry (DSC), X-ray diffractometry (XRD) as well as content uniformity, in vitro dissolution studies in $0.1 \mathrm{~N} \mathrm{HCl} \mathrm{pH} \mathrm{1.2,} \mathrm{phosphate} \mathrm{buffer} \mathrm{pH} 6.8$.

Results and Discussion: Results of the studies suggested that there were progressive disappearance or changes of prominent peaks in IR, X-ray diffraction and thermotropic drug signals in coevaporates and coprecipitates with increased amount of polymers. Moreover, the in vitro release of highly water soluble MET could be extended at higher drug:polymer ratios.

Conclusion: It was summarized that Eudragit RLPO had greater capacity of drug release than Eudragit RSPO and Comproitol 888 and its coevaporates in 1:5 drug:polymer ratio (F11)displayed extended drug release with comparatively higher dissolution rates ( $92.15 \%$ drug release at 12 hour) following near Zero order kinetics $\left(r^{2}=0.9822\right)$.

KEY WORDS: Extended release, Highly water soluble drug, Metformin hydrochloride, Solid dispersion 


\section{INTRODUCTION}

Many problems are associated with conventional multiple dosing regimen of long acting therapy, such as systemic accumulation of the drug leading to side effects or toxicities, irregular profile of the plasma drug level, and poor patient compliance. Controlled release drug delivery systems have the potential of solving these problems. Controlled release systems are the methods that can achieve therapeutically effective concentration of drug in the systemic circulation over an extended period of time with better patient compliance. Various approaches ranging from coated tablets and gels to biodegradable microparticles and osmotic systems have been used in an attempt to sustain the drug release from dosage forms. In most of the controlled release formulations, immediately upon placement in the release medium, an initial large bolus of drug is released before the release rate reaches a stable profile. This phenomenon is typically referred to as 'burst release'. Burst release leads to higher initial drug delivery and also reduces the effective life time of the device. For controlling drug release, the solid dispersion method is an alternative approach ${ }^{1}$.

The solid dispersion approach is commonly used to improve the dissolution properties of poorly water soluble drugs using hydrophilic polymeric carriers as dispersing agents. More recently, several studies on solid dispersions have been carried out using water insoluble carriers to produce sustained release pharmaceutical forms of freely water soluble drugs ${ }^{2-4}$. For this goal, different types of polymethacrylates (Eudragit) have been considered. The most interesting among acrylic polymers are highly permeable Eudragit RL and low permeable Eudragit RS, both are neutral copolymers of poly (ethylacrylate, methyl methacrylate) and trimethyl aminoethyl methacrylate chloride and are insoluble in water and digestive juices, but both swell and are permeable. Extended release systems are the methods that can achieve therapeutically effective concentrations of drug in systemic circulation over an extended period of time. Various researchers used the solid dispersion method for this purpose ${ }^{5-8}$. A combination of solid dispersion and extended release is one of the attractive approaches since supersaturation of the drugs can be achieved by employing solid dispersion technique. Keeping in mind all these facts, extending or controlling the release of a highly water soluble BCS class I (high solubility, high permeability)drug seems to be interesting using solid dispersion approach employing lipophilic carriers. Therefore, in present study, Eudragit RLPO and Eudragit RSPO have been used as retardants to prepare a novel extended release system of highly water soluble medicine metformin hydrochloride using coevaporation and coprecipitation techniques in order to extend their dissolution rates and to study the influence of type and concentration of Eudragit polymers on release profiles of the developed solid dispersion systems.

\section{MATERIALS AND METHODS}

\section{Materials:}

Metformin hydrochloride (MET) was gifted by Microlabs, Bangalore, India. Compritol 888 ATO (Compritol) was obtained ex gratia by Gattefosse, France. Eudragit RSPO (RSPO) and Eudragit RLPO (RLPO) were supplied as gift samples from Roehm Pharma, Germany. All other chemicals used were of analytical grade and double distilled water was used throughout the studies.

\section{Methods:}

\section{Prearation of metformin hcl solid dispersions}

Solid dispersions were prepared using three different polymers RSPO, RLPO and Compritol 888 ATO at two different drug:polymer ratios 1:1 and 1:5 using physical mixing, coevaporation and coprecipitation methods. Formulations were coded using method, polymer and ratio.

\section{Physical mixing method}

Physical mixtures were prepared by mixing the powdered drug and polymers in a mortar. Metformin $\mathrm{HCl}$ and polymers in two different weight ratios (1:1 and 1:5) were accurately weighed, mixed well in mortar for 5 minutes, sifted through sieve no. 80 and stored in vacuum desiccators.

\section{Coevaporation method}

Metformin $\mathrm{HCl}$ and different carriers were taken in different ratios (1:1 and 1:5), mixed well and dissolved in $20 \mathrm{ml}$ mixture $(1: 1)$ of dichloromethane and chloroform. The solvent was evaporated at $40^{\circ} \mathrm{C}$ for 5 minutes, dried completely in vacuum desiccators. The solid sample was pulverized gently in a mortar and passed through sieve no. 80 .

\section{Coprecipitation method}

Metformin $\mathrm{HCl}$ and different carriers were taken in different ratios (1:1 and 1:5), mixed well and dissolved in $20 \mathrm{ml}$ of dichloromethane and methanol. These masses were further transferred to $30 \mathrm{ml}$ diethyl ether at $0^{\circ} \mathrm{C}$ while being gently stirred. The precipitates were filtered using qualitative filter paper, spreaded on petri plate and dried to a constant weight. The dried samples were pulverized, screened through 80 mesh size sieve and stored in vacuum desiccators. 
Characterization of solid dispersion systems

\section{IR spectroscopy}

IR spectra of pure drug, polymers and formulated solid dispersions were obtained with a IR spectrophotometer (shimadzu IR-prestize-21) using KBR disks. The scanning range used was 4000 to $400 \mathrm{~cm}^{-1}$ at a scan of 1 minute.

\section{Differential scanning calorimetry}

Thermal analysis was performed on the drug, polymers and solid dispersions using a PERKIN-ELMER DSC-7. Samples (10-15mg) were weighed and scaled into $40 \mu \mathrm{L}$ aluminium pans. DSC runs were conducted over a temperature range of $70^{\circ} \mathrm{C}$ to $250^{\circ} \mathrm{C}$ at a rate of $10^{\circ} \mathrm{C} /$ minute in nitrogen atmosphere.

\section{X-Ray powder diffractrometry}

Differential patterns of drug, polymers and solid dispersions were recorded (PW 3040/60 X Pert PRO, Netherlands). A voltage of $40 \mathrm{kv}$ and a current of $30 \mathrm{~mA}$ for the generator was used, with $\mathrm{Cu}$ as the tube anode material. The solid samples were exposed to $\mathrm{Cu}-\mathrm{K}_{\mathrm{a}}$ radiation ( $\mathrm{a} 1=1.54060 \mathrm{~A}$, with an $\alpha 1 / \alpha 2$ ratio of 0.5$)$, over a range of $2 \theta$ angles from $10^{\circ} \mathrm{C}$ to $30^{\circ} \mathrm{C}$, at an angular speed of $(2 \theta)$ per minute.

\section{Determination of drug content}

Ten mg of each of the solid dispersion was accurately weighed and dissolved in $10 \mathrm{ml}$ phosphate buffer $\mathrm{pH}$ 6.8 and filtered. One $\mathrm{ml}$ of sample was withdrawn from each volumetric flask, suitably diluted and assayed spectrophotometrically at $232 \mathrm{~nm}$. The amount of MET in each sample was computed using calibration curve based on standard solution in phosphate buffer. Results were expressed both as the drug content (mg incorporated drug) and percent drug incorporation (actual amount of drug in solid dispersion vs initially added amount). The studies were conducted in triplicate.

Determination of in vitro drug release of solid dispersions

In vitro dissolution was performed using USP dissolution rate test apparatus I in $900 \mathrm{ml}$ of simulated gastric fluid $(0.1 \mathrm{~N}$ $\mathrm{HCl} \mathrm{pH} 1.2)$, simulated intestinal fluid (phosphate buffer $\mathrm{pH}$ 6.8) at an agitation rate of $100 \mathrm{rpm}$. The temperature of medium was maintained at $37 \pm 0.5^{\circ} \mathrm{C}$. An amount of solid dispersions equivalent to $75 \mathrm{mg}$ of drug were filled in transparent hard gelatin capsules and analyzed for drug release. At predetermined time intervals, aliquotes were withdrawn and replaced with an equal volume of fresh dissolution medium to maintain a constant dissolution volume. The samples were filtered, suitably diluted and assayed spectrophotometrically at $232 \mathrm{~nm}$.

\section{Evaluation of release kinetic of solid dispersions}

Data obtained from in vitro release studies was fitted to various kinetic equations to find out the mechanism of MET release form polymeric matrix system. The kinetic models used were zero order, First order, Higuchi and peppas model. The following plots were made: $Q_{t} V_{s} t$ (Zero order kinetic modal), log $\left(Q_{0}-Q_{t}\right)$ Vs t (first orderkinetic modael), $Q_{t}$ and $V_{s}$ square root of $t$ (Higuchi model)where $Q_{t}$ is the amount of drug release at time $t$ and $Q_{0}$ is the amount of drug present in solid dispersion, $\mathrm{Q}=\mathrm{Kt}^{\mathrm{n}}$ (Peppas model) where $\mathrm{Q}$ is the amount of drug release; $\mathrm{t}$ time; $\mathrm{k}$ is constant incorporating structural and geometrical characteristic of the release device and $n$ is the exponent indicative of the mechanism of release. Plots were subjected to regression analysis to find out the regression coefficient and hence the order of release.

\section{RESULTS AND DISCUSSION}

IR studies revealed that MET showed two typical bands at 3369 and $3296 \mathrm{~cm}^{-1}$ due to N-H stretching $\left(1^{\circ}\right)$, a band at $3170 \mathrm{~cm}^{-1}$ due to N-H stretching $\left(2^{\circ}\right)$, and characteristics bands at 1626 and $1567 \mathrm{~cm}^{-1}$ assigned to $\mathrm{C}=\mathrm{N}$ stretching. These peaks were unchanged in physical mixtures but disappeared in corresponding coevaporates (Fig. 1). These results suggested the possibility of intermolecular hydrogen bonding between PHC and RLPO in coevaporates. These interactions were made while the molecules were in

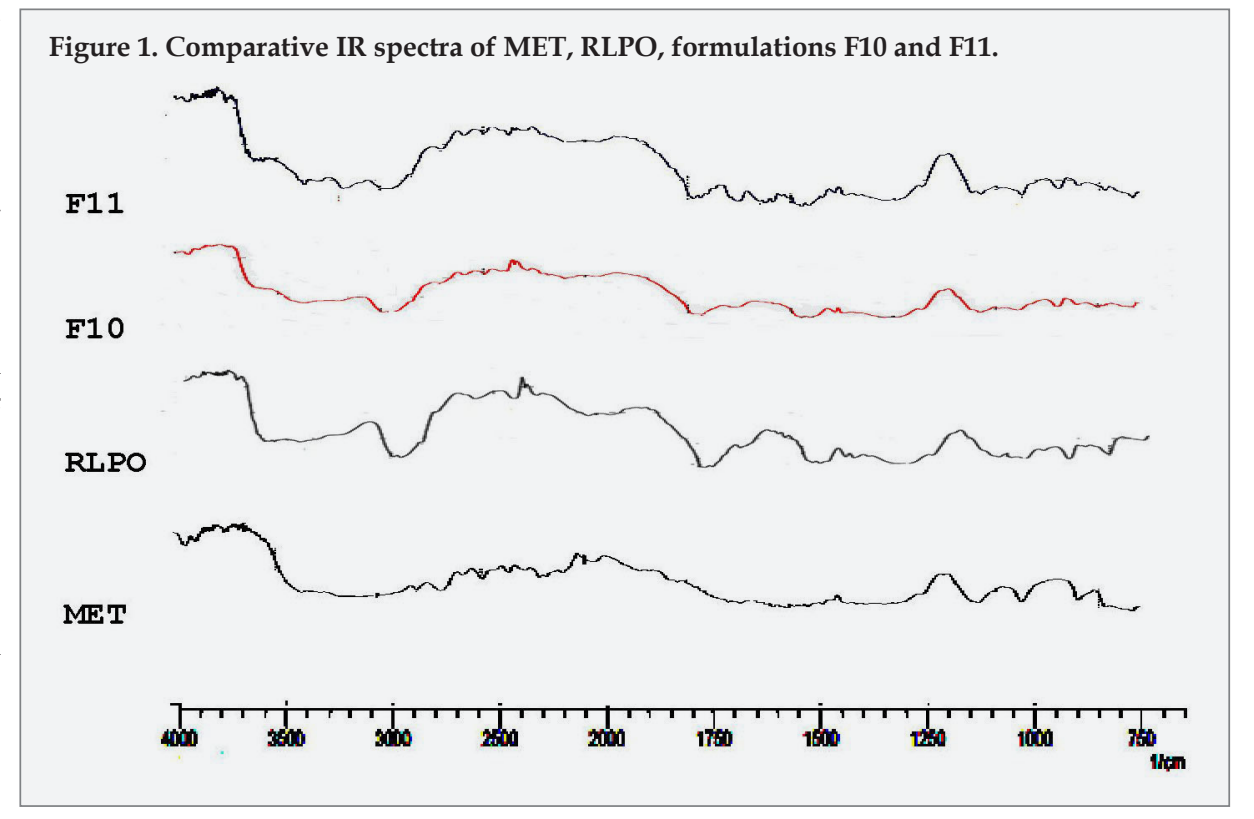


Figure 2. Comparative DSC thermograms of MET, RLPO, formulations F10 and F11

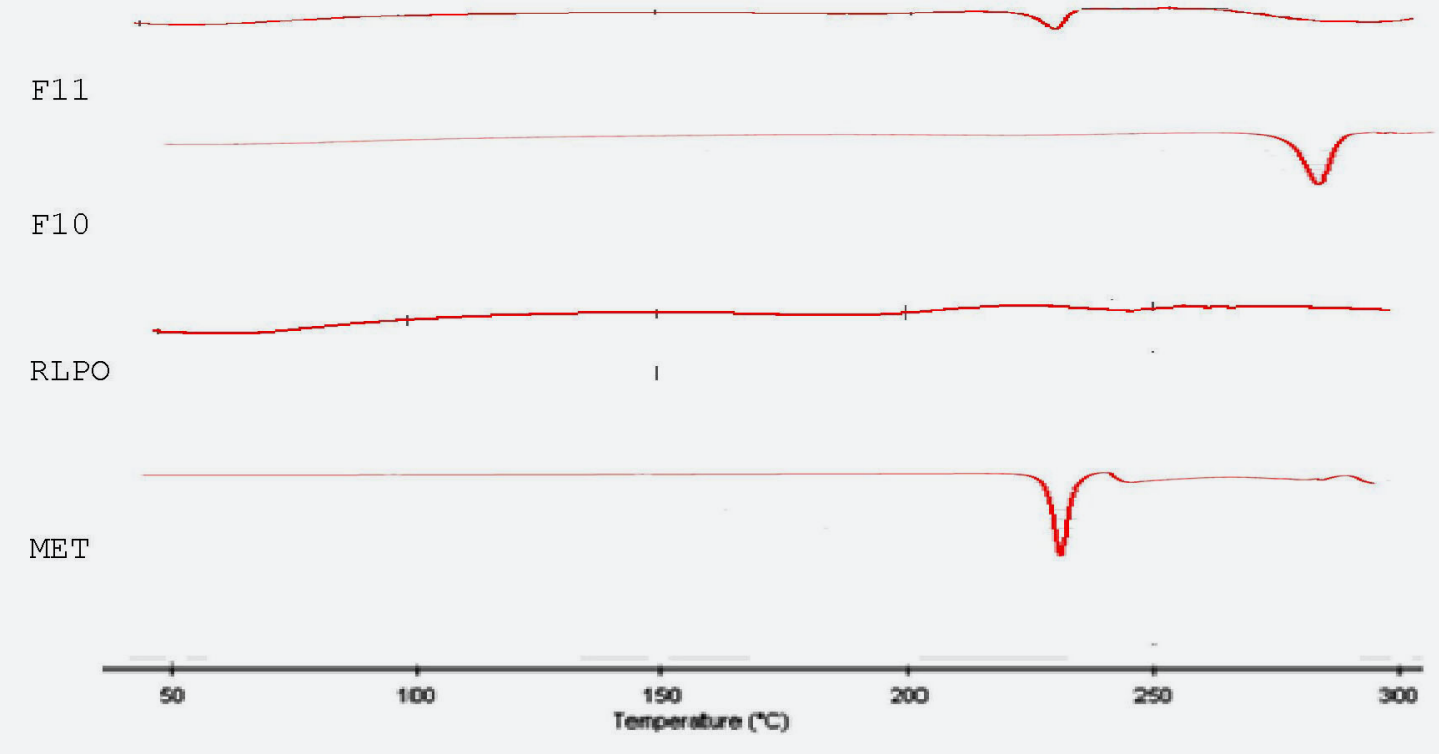

solution that is when the distances between the molecules were so small that association between the functional groups is possible 9 .

The DSC curves of pure MET exhibited an initially flat profile, followed by a single sharp endothermic peak representing the melting of the substance in the range $223-237^{\circ} \mathrm{C}\left(\mathrm{T}_{\text {onset }}=231.2, \mathrm{~T}_{\text {peak }}=233.33\right.$ and $\Delta \mathrm{H}_{\text {fusion }}=-313.51$ $\mathrm{J} / \mathrm{g})$. DSC curves of both RLPO and RSPO exhibited a flat thermal profile, indicative of the completely amorphous nature of these two polymers. The thermal curves of binary drug-polymer(s) mixtures, obtained by simple blending corresponded to the superimposition of those of the single components, indicating the absence of solid-state interactions and allowing assessment of drug-polymers compatibility in all the examined formulations (Fig.2).

XRD analysis of pure RSPO and RLPO confirmed their amorphous nature whereas the pure drug showed the diffractographic profiles of a crystalline product. When solid dispersions prepared with different polymer fraction were compared, it was clear that the systems prepared with lower polymer amounts still showed the typical signals of crystals, while increasing the polymer ratio progressively weakened their intensity. Crystallinity of drug in solid dispersion was always less than that observed in corresponding physical mixtures (Fig.3).

The actual drug contents of prepared solid dispersions in different samples revealed $95-100 \%$ of expected values with reproducible results. The drug content was uniform in all solid dispersion systems and was in good agreement with theoretical drug content (Table 1).
The release profiles of MET from the solid dispersion systems F7 to F12 were compared (Fig. 4). The dispersions of drugs in polymer matrices strongly influenced their dissolution rates which appeared lower and more gradual than that of pure drug. The significant dissolution observed for most solid dispersions containing MET at simulated gastric fluid became protonated at the acidic buffer ( $\mathrm{pH} 1.2)$ and made drug readily soluble, While in phosphate buffer ( $\mathrm{pH}$ 6.8), solid dispersions were found to extend drug release up to 12 hours because of decrease in solubility as compared with other media. In phosphate buffer ( $\mathrm{pH}$ 6.8), polymer dispersion of MET with RLPO usually displayed higher dissolution rates than F1-F6 formulations having RSPO because of greater quaternary ammonium group content, which activity sites for electrostatic interactions. Eudragit RSPO is only permeable to water; hence drug release was relatively retarded with respect to freely permeable Eudragit RLPO. On the other hand, Eudragit RSPO swells in aqueous natural and artificial digestive juices, rendering itself permeable to these liquids. The mechanism of drug release would probably be through direct dissolution of partially embedded drug followed by diffusion of embedded drug via the matrix pores. These results might be due to the fact that Eudragit RLPO is capable of swelling without disintegration at $\mathrm{pH}$ 1.26.8 and due to its permeability, permeation occurred. Coprecipitates containing Eudragit RSPO at higher drug to polymer ratios were able to slow down the diffusion rate of drug.

On analyzing regression coefficient values of all batches, it was found that F11 followed Zero order kinetics $\left(r^{2}=0.9822\right)$. To confirm diffusion, the data were fitted to Korsemeyer- 
Figure 3. Comparative X-ray diffractograms of MET, RLPO, formulations F10 and F11

F11<smiles>CCCCCCC</smiles>

F10

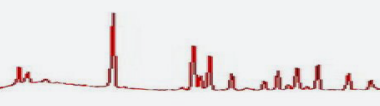

RLPO

MET

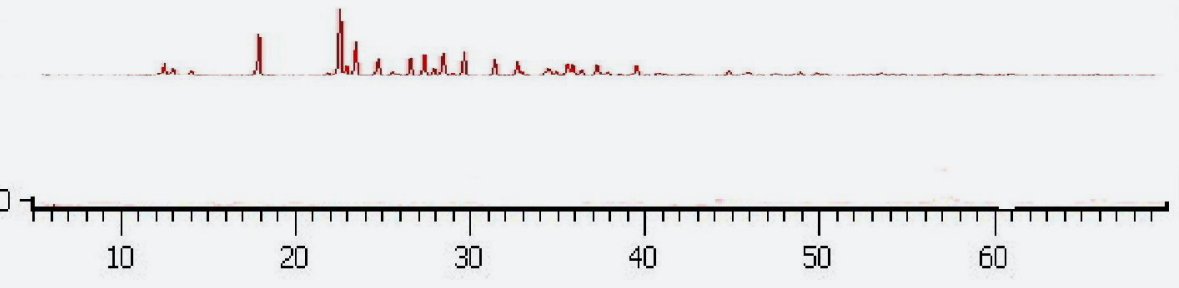

Table 1. Drug content studies of solid dispersion formulations.

\begin{tabular}{|c|c|c|c|c|}
\hline \multirow{2}{*}{$\begin{array}{l}\text { Formulation } \\
\text { Number }\end{array}$} & \multirow{2}{*}{$\begin{array}{l}\text { Formulation } \\
\text { Code }\end{array}$} & \multicolumn{2}{|c|}{ Loading efficiency (mg) } & \multirow[b]{2}{*}{ Percent drug incorporation } \\
\hline & & $\begin{array}{c}\text { Theoretical } \\
\text { drug content }(\%)\end{array}$ & $\begin{array}{l}\text { Actual drug content } \\
(\%)^{*}\end{array}$ & \\
\hline F1 & PMRS1 & 50.00 & $46.57 \pm 0.001$ & 98.17 \\
\hline F2 & CERS1 & 50.00 & $45.48 \pm 0.003$ & 98.32 \\
\hline F3 & CPRS1 & 50.00 & $45.83 \pm 0.002$ & 99.49 \\
\hline $\mathrm{F} 4$ & PMRS5 & 16.67 & $15.21 \pm 0.003$ & 98.13 \\
\hline F5 & CERS5 & 16.67 & $13.11 \pm 0.001$ & 99.99 \\
\hline F6 & CPRS5 & 16.67 & $13.45 \pm 0.002$ & 99.85 \\
\hline F7 & PMRL1 & 50.00 & $47.35 \pm 0.002$ & 95.24 \\
\hline F8 & CERL1 & 50.00 & $46.55 \pm 0.001$ & 97.16 \\
\hline F9 & CPRL1 & 50.00 & $45.14 \pm 0.003$ & 99.19 \\
\hline F10 & PMRL5 & 16.67 & $14.26 \pm 0.004$ & 95.45 \\
\hline F11 & CERL5 & 16.67 & $15.26 \pm 0.002$ & 98.52 \\
\hline F12 & CPRL5 & 16.67 & $13.65 \pm 0.001$ & 97.12 \\
\hline F13 & PMCT1 & 50.00 & $47.16 \pm 0.003$ & 98.16 \\
\hline F14 & CECT1 & 50.00 & $46.25 \pm 0.002$ & 100.27 \\
\hline F15 & CPCT1 & 50.00 & $45.28 \pm 0.002$ & 96.65 \\
\hline F16 & PMCT5 & 16.67 & $14.33 \pm 0.001$ & 97.82 \\
\hline F17 & CECT5 & 16.67 & $13.03 \pm 0.002$ & 98.18 \\
\hline F18 & СРCT5 & 16.67 & $15.13 \pm 0.001$ & 99.12 \\
\hline
\end{tabular}

Peppas equation. The model fitting parameters of solid dispersion formulations are summarized in Table 2. The formulations with $0.5<\mathrm{n}<1$ appeared to indicate nonFickian type of release mechanism meaning that the drug release couples diffusion with erosion so called anomalous diffusion and may indicate that the release is controlled by more than one process.

\section{CONCLUSION}

The results revealed that the preparation conditions did not make polymorphic changes or amorphization of drug within the polymer network and higher amount of polymer displayed diluting effect on physicochemical properties of drug within prepared dispersions. The release of highly water soluble MET could not be controlled at lower 
Figure 4. Comparative drug release profiles of formulations F7-F12

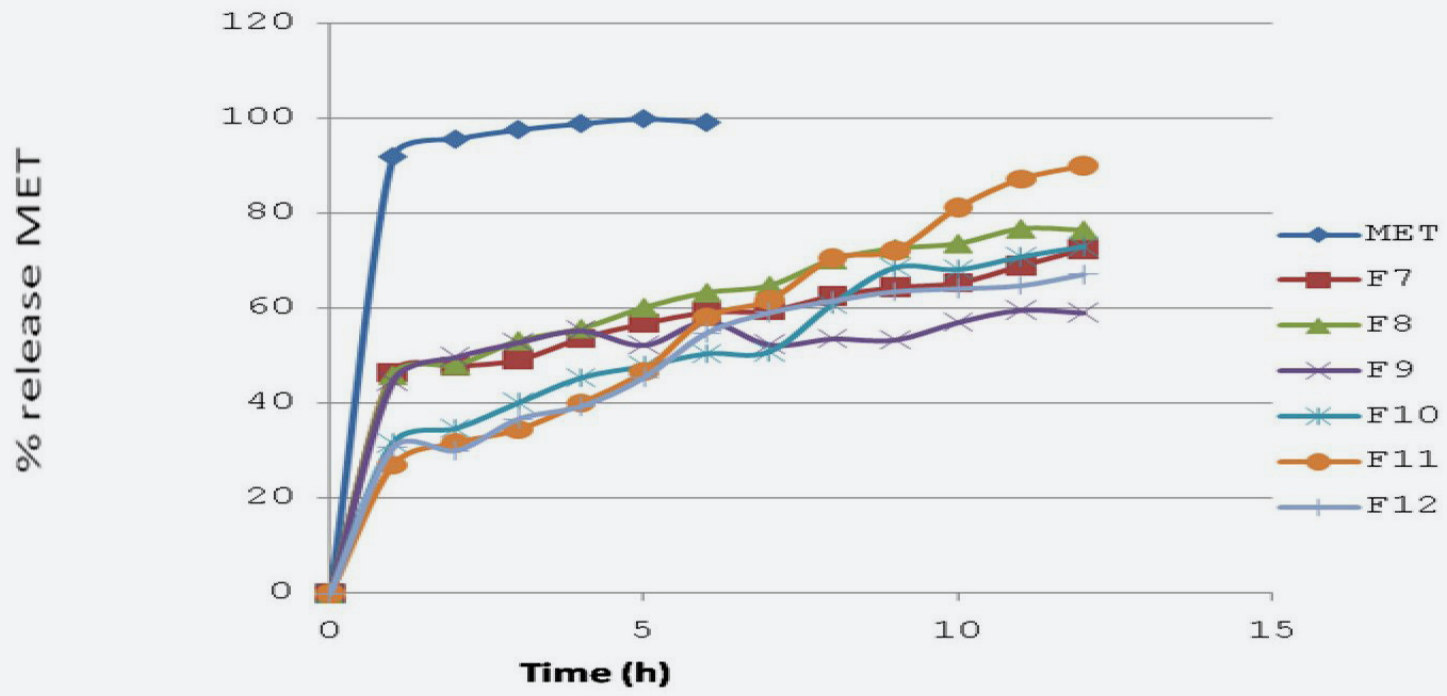

Table 2. Model fitting parameters of solid dispersion formulations

\begin{tabular}{|c|c|c|c|c|c|c|c|c|}
\hline \multirow{2}{*}{$\begin{array}{c}\text { Formulation } \\
\text { Number }\end{array}$} & \multicolumn{2}{|c|}{ Zero order } & \multicolumn{2}{|c|}{ First order } & \multicolumn{2}{|c|}{ Higuchi } & \multicolumn{2}{|c|}{ Korsmeyer-Peppas } \\
\hline & $r^{2}$ & k & $r^{2}$ & k & $r^{2}$ & k & $r^{2}$ & n \\
\hline F1 & 0.7508 & 3.3279 & 0.3322 & 0.0388 & 0.7762 & 13.8432 & 0.6168 & 0.8116 \\
\hline F2 & 0.6329 & 2.5427 & 0.4035 & 0.0478 & 0.7222 & 11.6739 & 0.5953 & 0.769 \\
\hline F3 & 0.5486 & 2.0835 & 0.4346 & 0.0453 & 0.7174 & 10.9613 & 0.5757 & 0.7335 \\
\hline F4 & 0.8295 & 4.0693 & 0.2705 & 0.0320 & 0.8337 & 16.2556 & 0.6696 & 0.8805 \\
\hline F5 & 0.6678 & 2.8125 & 0.3832 & 0.0452 & 0.8157 & 1.3 .8216 & 0.6261 & 0.8172 \\
\hline F6 & 0.6073 & 2.1933 & 0.4221 & 0.5186 & 0.7565 & 10.9929 & 0.6040 & 0.7560 \\
\hline F7 & 0.8038 & 3.7509 & 0.2857 & 0.0332 & 0.7675 & 14.4099 & 0.6327 & 0.8370 \\
\hline F8 & 0.8451 & 4.4393 & 0.1967 & 0.0225 & 0.8202 & 17.3365 & 0.6539 & 0.8836 \\
\hline F9 & 0.6314 & 2.5093 & 0.4036 & 0.0479 & 0.6963 & 11.1330 & 0.5868 & 0.7570 \\
\hline F10 & 0.9347 & 4.8702 & 0.1949 & 0.0239 & 0.8213 & 17.2173 & 0.7188 & 0.9439 \\
\hline F11 & 0.9822 & 6.7482 & 0.0039 & 0.0004 & 0.7794 & 21.5433 & 0.5929 & 0.8184 \\
\hline F12 & 0.9234 & 4.6596 & 0.2341 & 0.0288 & 0.8199 & 16.646 & 0.7285 & 0.9503 \\
\hline F13 & 0.8719 & 4.1596 & 0.2554 & 0.0305 & 0.8119 & 15.5832 & 0.6670 & 0.8744 \\
\hline F14 & 0.7603 & 3.4486 & 0.3242 & 0.0377 & 0.8103 & 14.7868 & 0.6277 & 0.8273 \\
\hline F15 & 0.6526 & 2.6020 & 0.3952 & 0.0472 & 0.8065 & 12.9358 & 0.6009 & 0.7698 \\
\hline F16 & 0.8479 & 3.9697 & 0.2804 & 0.0338 & 0.8529 & 16.0637 & 0.6703 & 0.8724 \\
\hline F17 & 0.9259 & 5.1284 & 0.2094 & 0.0252 & 0.8250 & 18.4020 & 0.7133 & 0.9529 \\
\hline F18 & 0.8077 & 3.4207 & 0.3343 & 0.0405 & 0.8541 & 14.5495 & 0.6652 & 0.8542 \\
\hline
\end{tabular}

polymer ratio. Drug:RLPO coevaporates in 1:5 ratio could extend release of freely water soluble drug and could be suggested to be incorporated to formulate suitable oral solid dosage forms such as capsules or tablets. The studies provided better forecasting and understanding of solid dispersions as an alternative approach to controlled drug delivery and possibly utilizing such particulate systems to develop better delivery systems over existing ones.

\section{REFERENCES}

1. Giri TK, Kumar k, Alexander A, Ajazuddin, Badwaik H, Tripathi DK. A novel and alternative approach to controlled release drug delivery system based on solid dispersion technique. Bull Faculty Pharm, Cairo university 2012; 50:147159.

2. Hiroshi Y, Tetsuya O, Yoshio K, Katsutoshi O, Tadashi O. Application of the solid dispersion method to controlled release of medicine I. Controlled release of water soluble medicine by using solid dispersion. Chem Pharm Bull 1991; 39: 465-467.

3. Fillipis PD, Zingone G, Gibellini M, Rubessa f, Rupena P. Dissolution rates of different drugs from solid dispersions 
with Eudragit RS. Eur J Pharm Sci 1995; 3: 265-271.

4. Ho G, Hwang GC. Development of extended release solid dispersions of non steroidal antiinflammatory drugs with aqueous polymeric dispersions: optimization of drug release via a curve fitting technique. Pharm Res 1992; 9: 206-210.

5. Desai J, Alexander K, Riga A. Characterization of polymeric dispersions of dimenhydrinate in ethyl cellulose for controlled release. Int J Pharm 2006; 308: 115-123.

6. Chen D, Tsay RJ, Lin H, Chen H, Chao SC, Ku H. Stabilization of sustained release effect of misoprostol with methacrylate copolymer. Int J pharm 2000; 203: 141-148.
7. Juan MA, Cruz R, Hernandez E. Preparation and characterization of furosemide-eudragit controlled release systems. Int J Pharm 2000; 195: 45-53.

8. Khan MA, Karnachi AA, Agarwal V, Vaithiyalingam SR, Nazzi S., Reddy IK. Stability characterization of controlled release coprecipitates and solid dispersions. J Control Rel 2000; 63: 1-6.

9. Dahiya S, Pathak K, Sharma R. Development of extended release coevaporates and coprecipitates of promethazine hydrochloride with acrylic polymers: formulation considerations. Chem Pharm Bull 2008; 56: 504-508. 